\title{
Effect of organic acid treated diets on growth, apparent nutrient digestibility and
} faecal moisture of broiler chickens

*Ndelekwute, E. K., Assam, E. D., Ekere, P. C. and Ufot, U. E.

${ }^{1}$ Department of Animal Science, University of Uyo, Uyo, Nigeria.

*Corresponding author E-mail: ndelekwute.ek@gmail.com

\section{Abstract}

An experiment was conducted to determine the effect of four organic acids (acetic, butyric, citric and formic acids) inclusion in the diets of broilers on growth, nutrient digestibility and faecal moisture. One hundred and fifty one day old Arbor-Acre-plus chicks were used. There were five dietary treatments. Basal diet which served as control contained no organic acid was formulated, while diets 2, 3, 4 and 5, respectively contained $0.25 \%$ acetic, butyric, citric and formic acids formed by adding $0.25 \%$ of each acid to the basal diet. Each treatment was replicated three times with 10 birds per replicate, arranged in completely randomized design (CRD). Diets were both isocaloric and isonitrogenous. The experiment lasted for 4 from the fourth to the eight week. Feed and water were given ad libitum. There were no significant differences $(P>0.05)$ in live weight, daily gain, feed intake, feed: gain ratio and protein efficiency ratio. Acetic acid significantly $(P<0.05)$ increased water intake. Fecal moisture was significantly reduced by citric and butyric acids. Higher crude protein digestibility was achieved by butyric acid (69.98\%) citric (69.67\%) and formic acid (71.33\%) than the control (63.75\%). Digestibility of $C F, E E$ and ash was significantly $(P<0.05)$ higher in all the organic acid groups. Feeding of diets treated with $0.25 \%$ of the test organic acids at the finisher phase, in that despite improved digestibility of nutrients the practice should not be encouraged for reasons of insignificant growth performance.

\section{Introduction}

One of the nutritional strategies for enhancing the rapid growth of broilers had been the addition of antibiotics as additives to feed (Windisch, et al., 2007). However, the recent concerns about antibiotics resistance in livestock industry necessitated the need for alternative strategies to improve animal performance and health without the use of antibiotics (Chen et al., 2005). Some dietary products are therefore being evaluated to replace antibiotics in poultry diets. These products include probiotics (Cheeson, 1994), prebiotic (Patterson and Burkholder, 2003), yeast culture (Gao et al., 2008), essential oils and spices (Windisch et al., 2007) and organic acids (Leeson et al., 2005). Organic acids (carboxylic acids) have been used for decades in feed preservation, protection of feed from bacterial and fungal destruction (Paul et al., 2007). Reports of the potentials of organic acids to support growth of broilers has been hinged on their antibacterial effect and stimulation of villi growth (Leeson et al., 2005).

Recently, organic acids were reported to improve both digestibility and growth of broiler chickens when added at the starter phase (Ndelekwute et al., 2010; Ndelekwute et al., 2011). Other reports on effectiveness of organic acids in the enhancement of broiler chicken growth showed that diets started at the starter phase was feasible (Leeson et al., 2005; Paul et al., 2007). Prolonged dietary organic acids when commenced at the starter phase would increase the quantity of organic acid used 
and invariably the cost of production. This shortcoming could be obviated if feeding of dietary organic acids is only at the finisher phase.

Therefore, the objective of this study was to evaluate the effect of diets treated with organic acids (acetic, butyric, citric and formic acids) fed at finisher phase on digestibility and growth performance of broiler chickens.

\section{Materials and Methods Site of Experiment}

The experiment was conducted at the Teaching and Research Farm of Department of Nutrition and Forage Science Michael Okpara University of Agriculture, Umudike, Nigeria. Umudike is situated on latitude $5^{\circ} 28^{1} \mathrm{~N}$ and longitude $7^{\circ}$ $32{ }^{1} \mathrm{E}$ and lies at an altitude of 122 metres above sea level, with average rainfall of
$2000 \mathrm{~mm}$. The average relative humidity during the experiment was $72 \% \pm 5$ (The information was obtained from the Meteorology Department of the National Root Crops Research Institute, Umudike, Nigeria). The average ambient temperature of the poultry house was $28^{\circ \mathrm{C}}$.

\section{Experimental Design}

One hundred and fifty one day old chicks of Arbor Acre strain were used for this experiment. The experimental was a completely randomized design. The birds were divided into five treatments. Each treatment was replicated three times, each having 10 birds. Each treatment group was fed acetic acid (AA), butyric acid (BA), citric acid (CA) and formic acid (FA) treated diets respectively at $0.25 \%$, at the finisher phase. The control group received a diet with no organic acid. A basal diet without organic acid was fed to birds at the starter phase for four weeks.

\begin{tabular}{|c|c|c|}
\hline Ingredients (\%) & Starter & Finisher \\
\hline Maize & 53.00 & 54.00 \\
\hline Soybean meal & 30.00 & 27.00 \\
\hline Fish meal & 3.00 & 3.00 \\
\hline Palm kernel cake & 6.30 & 6.30 \\
\hline Wheat offal & 4.00 & 6.00 \\
\hline Bone meal & 3.00 & 3.00 \\
\hline Salt & 0.25 & 0.25 \\
\hline Lysine & 0.10 & 0.10 \\
\hline Methionine & 0.10 & 0.10 \\
\hline Premix* & 0.25 & 0.25 \\
\hline Total & 100 & 100 \\
\hline \multicolumn{3}{|l|}{$\begin{array}{l}\text { Calculated nutrient } \\
\text { composition }(\%)\end{array}$} \\
\hline Crude Protein & 22.05 & 20.10 \\
\hline Crude Fibre & 4.13 & 5.55 \\
\hline Ether Extract & 4.10 & 5.00 \\
\hline Calcium & 1.08 & 1.00 \\
\hline Phosphorus & 1.01 & 0.80 \\
\hline Lysine & 1.10 & 0.90 \\
\hline Methionine & 0.50 & 0.40 \\
\hline Energy (KcalME/kg diet) & 2847 & 2850 \\
\hline \multicolumn{3}{|c|}{$\begin{array}{l}\text { * Starter premix supplied/kg diet: Thiamin } 2 \mathrm{mg} \text {, Riboflavin } 6 \mathrm{mg} \text {, pyridoxine } 4 \mathrm{mg} \text {, Niancin } 40 \mathrm{~m} \\
\text { cobalamine } 0.05 \mathrm{~g} \text {, Biotin } 0.08 \mathrm{mg} \text {, chooline chloride } 0.05 \mathrm{~g} \text {, Manganese } 0.096 \mathrm{~g} \text {, Zinc } 0.06 \mathrm{~g} \text {, Iror } \\
0.024 \mathrm{~g} \text {, Copper } 0.006 \mathrm{~g} \text {, Iodine } 0.014 \mathrm{~g} \text {, Selenium } 0.24 \mathrm{mg} \text {, Cobalt } 0.024 \mathrm{mg} \text { and Antioxidant } \\
0.125 \mathrm{~g} \text {.Finisher premix supplied per kg diet; vitamin A } 10,0001 . \mathrm{u} ., \text { vitamin } \mathrm{D}_{3} 12,0001 . \mathrm{u} \text {. } \\
\text { Vitamin E } 201 . \mathrm{U} \text {., Vitamin K } 2.5 \mathrm{mg} \text {, thiamine } 2.0 \mathrm{mg} \text {, Riboflavin } 3.0 \mathrm{mg} \text {, pyridoxine } 4.0 \mathrm{mg} \text {, } \\
\text { Niacin } 20 \mathrm{mg} \text {, cobalamin } 0.05 \mathrm{mg} \text {, pantthemic acid } 5.0 \mathrm{mg} \text {, Folic acid } 0.5 \mathrm{mg} \text {, Biotin } 0.08 \mathrm{mg} \text {, } \\
\text { choline chloride } 0.2 \mathrm{mg} \text {, Manganese } 0.006 \mathrm{~g} \text {, Zinc } 0.03 \mathrm{~g} \text {, Copper } 0.006 \mathrm{~g} \text {, Iodine } 0.0014 \mathrm{~g} \text {, } \\
\text { Selenium } 0.24 \mathrm{~g} \text {, cobalt } 0.25 \mathrm{~g} \text { and antioxidant } 0.125 \mathrm{~g} \text {. **Calculated }\end{array}$} \\
\hline
\end{tabular}




\section{Experimental birds, diets and management}

A single starter diet (Table 1) without organic acid was formulated and fed to all the birds at the starter phase. At the finisher phase five diets was formulated which were isonitrogenous and isocaloric (Table 1).

The birds were brooded for three weeks. At the starter phase Newcastle disease and Gumboro disease vaccines were administered. At the end of fourth week, they were randomly separated into treatment groups and weighed. Feeding of organic acid-treated-finisher-diets were given at the end of fourth week and lasted for four weeks. Feed and water were given ad libitum.

\section{Data Collection}

Data on feed intake, water intake and body weight were collected. Feed and water intakes were determined daily by subtracting the leftover from the quantity given the previous day $(\mathrm{Feed} /$ water intake $=$ Quantity fed - leftover). At the end of the week, they were summed up and divided by the number of birds per replicate. The value obtained was then divided by 7 to give average daily feed or water intake. The body weight was measured weekly.

\section{Digestibility Study}

Total collection method was used for the digestibility trials in metabolism. Before the birds were introduced to the cages, both the metabolism room and cages were thoroughly washed and disinfected. At the end of week 4 of feeding two birds from each replicates giving a total of 30 birds were assigned to the metabolic cage. The weight of each bird used was similar to the average weight of the replicate from which it was taken. The birds were fed and given water ad libitum. The birds were acclimatized for four days before faecal collection. Then $250 \mathrm{~g}$ of feed was offered daily to each bird. Each morning before feeding commenced, leftover feed was recorded and feed intake noted.

Faecal droppings were collected and weighed on daily basis for three days. Collected faeces were immediately taken to the laboratory where they were oven dried at $60^{\circ} \mathrm{C}$ to constant weight. Dry faecal samples were ground to pass $1 \mathrm{~mm}$ sieve. The three days faecal collection was pooled and thoroughly mixed together. A portion was taken, stored in a refrigerator from which proximate analysis was carried out according to AOAC. (1990).

\section{DataAnalysis}

Data were subjected to one way analysis of variance. Means were separated using New Duncan Multiple Range Test according to Steel and Torrie (1980).

\section{Results and Discussion}

Table 2 shows the effect of feeding organic acids on growth performance of finisher broiler chickens. Dietary organic acids did not influence live weight, feed intake, feed gain ratio and protein utilization significantly $(\mathrm{P}>0.05)$. The initial live weight which was the body weight at the end of starter phase was statistically $(\mathrm{P}>0.05)$ similar. This result runs contrary to the report of Lesson et al. (1995) that butyric acid improved growth. However their feeding of butyric acid started from starter phase. Result could be ascribed to early colonization of the gut by gram negative pathogenic bacteria, during the starter phase when organic acids were not fed. According to Choct (2009) these pathogens colonize the gut of chicks as early as one week of age affecting nutrient digestion and utilization. Beneficial microflora such as lactic acid bacteria which encourage feed digestion are said to be excluded and incapacitated (Sun, 2004). The pathogenic microflora is able to achieve gut colonization during chick early 


\section{Effects of organic acids on growth and apparent nutrient digestibility in broiler chickens}

life because underdeveloped gut is susceptible to pathogenic microflora colonization (Ao and Choct, 2006). These organisms produce intestinal amines and ammonia by fermentation of nutrients which retards digestion and absorption due to short villi Choct (2009). It has been suggested that feeding of organic acids during early life of broilers, could control these pathogens and improve growth (Waldroup et al., 1995). However, the marginal superiority exhibited by acetic, citric and formic acids suggests that they could be better improvement if the acids levels were of higher doses at the finisher phase.

Table 2: Effect of Organic Acid Treated D iets on Performance of Broilers

\begin{tabular}{lllllll}
\hline Parameters & CON & AA & BA & CA & FA & SEM \\
\hline Initial live weights $(\mathrm{g})$ & 560.00 & 556.67 & 540.00 & 540.00 & 546.67 & 11.95 \\
Final live weight $(\mathrm{g})$ & 1705.33 & 1718.00 & 1683.33 & 1701.33 & 1711.00 & 17.05 \\
Daily weight gain $(\mathrm{g})$ & 40.90 & 41.48 & 40.83 & 41.48 & 41.58 & 2.63 \\
Daily feed intake $(\mathrm{g})$ & 109.15 & 112.93 & 107.00 & 111.32 & 112.25 & 3.60 \\
Feed: gain ratio & 2.67 & 2.72 & 2.62 & 2.68 & 2.70 & 0.11 \\
Daily protein intake (g) & 21.67 & 22.42 & 21.23 & 22.09 & 22.28 & 1.22 \\
Protein efficiency ratio & 1.89 & 1.85 & 1.92 & 1.88 & 1.87 & 0.09 \\
Daily water intake (ml) & $183.73^{\mathrm{b}}$ & $189.83^{\mathrm{ab}}$ & $182.19^{\mathrm{b}}$ & $195.00^{\mathrm{a}}$ & $198.57^{\mathrm{a}}$ & 5.78 \\
Water: feed ratio & 1.68 & 1.68 & 1.70 & 1.75 & 1.77 & 0.13
\end{tabular}

abc- means along the same row with different superscripts are significantly different $(\mathrm{p}<0.05)$.

$\mathrm{SEM}=$ Standard error mean $. \mathrm{CON}=$ Control $. \mathrm{AA}=$ Acetic acid, $\mathrm{BA}=$ Bu tyric acid, $\mathrm{CA}=\mathrm{Citric}$ acid, $\mathrm{FA}=$ Formic acid.

\section{Nutrient Digestibility}

The effect of diets treated with organic acids on faecal moisture and apparent nutrient digestibility is shown in Table 3. Dietary treatments with organic acids significantly $(\mathrm{P}<0.05)$ influenced all parameters measured except dry matter, nitrogen free extracts and energy. Butyric and citric acid treated diets significantly showed the capacity to reduce faecal moisture than the control, thus indicating that they could be used to reduce the incidence of wet litter. Protein digestibility was significantly $(\mathrm{P}<0.05)$ improved by all the organic acids compared with the the control except acetic acid which was similar with the control. Crude fibre, ether extract and ash digestibility was significantly higher $(\mathrm{P}>0.05)$ in groups which consumed feed that contained organic acids compared to control.

Despite improved digestibility of protein, by butyric, citric and formic acids, that did not translate into significant improvement in live weight performance of birds as shown in Table 3). This could be due to the fact that protein which is essential for growth was better utilized at the starter than the finisher phase (Obioha, 1992; Olumu, 1995; Oluyemi and Roberts, 2000). Also, this underscores the fact that nutrients could be well digested but may not be well utilized. In this case, activities of gut colonizing microflora could have reduced the absorptive capacity of the gut to absorb the digested nutrient for metabolism (Choct, 2009). This view is strongly supported by reports (Waldroup et al., 1995; Dibner, 2004; Islam et al.,2008 that formic and citric acids improved protein and fat digestibility in broilers. However, Hernandez et al. (2006) observed improved dry matter digestibility when butyric and acetic acids were fed, was contrary to findings in this study. 
Ndelekwute, Assam, Ekere and Ufot

Table 3: Effect of Organic Acid Treated Diets on Digestibility and Faecal moisture of Broiler chickens

\begin{tabular}{lllllll}
\hline Parameters & CON & AA & BA & CA & FA & SEM \\
\hline Faecal Moisture & $77.33^{\mathrm{a}}$ & $73.93^{\mathrm{ab}}$ & $70.57^{\mathrm{bc}}$ & $66.63^{\mathrm{c}}$ & $76.74^{\mathrm{a}}$ & 3.34 \\
Dry matter & 66.44 & 65.05 & 70.63 & 68.93 & 69.55 & 1.45 \\
Crude protein & $63.75^{\mathrm{b}}$ & $66.98^{\mathrm{ab}}$ & $69.98^{\mathrm{a}}$ & $69.67^{\mathrm{a}}$ & $71.33^{\mathrm{a}}$ & 3.78 \\
Crude fibre & $31.83^{\mathrm{c}}$ & $36.88^{\mathrm{a}}$ & $35.42^{\mathrm{b}}$ & $34.76^{\mathrm{b}}$ & $37.79^{\mathrm{a}}$ & 2.76 \\
Ether extract & $60.76^{\mathrm{c}}$ & $67.85^{\mathrm{b}}$ & $79.53^{\mathrm{a}}$ & $80.69^{\mathrm{a}}$ & $79.49^{\mathrm{a}}$ & 5.67 \\
NFE & 69.01 & 69.42 & 71.00 & 71.31 & 71.40 & 2.23 \\
Crude ash & $54.87^{\mathrm{c}}$ & $60.12^{\mathrm{b}}$ & $62.86^{\mathrm{ab}}$ & $64.74^{\mathrm{a}}$ & $64.15^{\mathrm{a}}$ & 4.79 \\
Energy utilization & 65.11 & 67.28 & 68.20 & 66.70 & 67.05 & 2.00 \\
\hline
\end{tabular}

$\mathrm{abc}=$ means along the same column with different superscripts are significantly different $(\mathrm{P}<0.05) . \mathrm{SEM}=$ Standard error of means, $\mathrm{CON}=$ control, $\mathrm{AA}=$ Acetic acid, $\mathrm{BA}=$ Butyric acid, $\mathrm{CA}=$ Citric acid, $\mathrm{FA}=$ Formic acid.

\section{Conclusion}

Though butyric, citric and formic acids improved digestibility of crude protein, ether extract, ash and fibre they are not recommended to be fed to broilers at the finisher phase at the current concentration in the feeds, because this did not lead to better growth performance. It is suggested therefore that the concentration of the organic acids in the diets be increased at the finisher phase.

\section{Acknowledgement}

The authors acknowledge the financial support of the University of Uyo, Nigeria and the Tertiary Education Trust Fund (TETFUND) of Nigeria.

\section{References}

Ao, Z. and Choct, M. 2006. Perspective on early nutrition and life - long health of Chickens Proc. $3^{\text {rd }}$ International Broiler nutritionists Conf. Auckland, Newzealand. $125-142$.

AOAC. 1990. Official Methods of Analysis. $14^{\text {th }}$ edition. Washington D.C., USA.

Cheeson, A. 1994. Probiotics and other intestinal mediators. In: Principles of pig science. (Cole, D. J. A., Wiseman, J. and Varley, M. A. Eds.). Nottingham University Press: $197-214$.

Chen, Y. J., Son, K. S., Min, B. J., Cho, J. H., Kwon, O. S and Kim, I. H. 2005. Effects of dietary probiotic in growth performance, nutrients digestibility, blood characteristics and fecal noxious gas content in growing pigs. Asian-Aust. J. Anim. Sci. 18(10): 1464 - 1468.

Choct, M. 2009. Managing gut health through nutrition. Brit. Poult. Sci. 50(1): $9-15$.

Dibner, J. 2004. Organic acids: Can they replace antibiotic growth promoters. Feed Int. Dec. 25(12): $14-16$

Gao, J., Zhang, H. J., Yu, S. H., Wu, S. G., Yoon, I. Quigley, J., Gao, Y. P. and Qi, G. H. 2008. Effects of yeast culture in broiler diets on performance and immuno modulatory functions. Poult. Sci. 87: $1377-1384$.

Hernandez, F., Madrid, J., Garcia V. Orengo, J. and Megias, M. D 2006. Influence of two plant extracts on broilers performance, 
Effects of organic acids on growth and apparent nutrient digestibility in broiler chickens

digestibility and digestive organ size. Poult. Sci. 83: 169 - 174.

Islam, M. Z., Khandakar, Z. H., Chowdhury, S. D. and Islam, K. M.S. 2008. Effect of citric acid and acetic acid on performance of broilers. J. Bangladesh Agric. Univ. 6(2): 315 - 320.

Leeson, S., Namkung, H., Ankongiovanni, $H$. and Lee, $\mathbf{E}$. H. 2005. Effect of butyric acid on the performance and carcass yield of broiler chickens. Poult. Sci. 84: $1418-1422$.

Ndelekwute, E. K., Uzegbu, H. O., Inyang, U. O., Igwe, R. J., Ogbe, S. E., Agbara, D. O. and Ndukwu, P. C. 2010. Substitution of crystalline lysine with solar-driedblood meal: Economic implications in starter-finisher broiler diets.Proc. $35^{\text {th }}$ Conf. Nig. Soc. Anim. Prod., Ibadan, Nigeria $14-17$.

Ndelekwute, E. K., Amaefule, K. U., Anigbogu, N. M. and Onen, G. E. 2011. Effect of organic acid-treated diets on nutrient digestibility and fecal moisture of broiler chickens.Proc. $36^{\text {th }}$ Annual Conf. Nig. Soc.Anim. Prod, Abuja, Nigeria. $731-733$

NRC 1994. Nutrient Requirement for poultry. $9^{\text {th }}$ ed. National Academy press. Washington DC, USA.

Obioha, F.C. 1992. A Guide to Poultry Production in the Tropics. $1^{\text {st }}$ ed. Ecena Pub. Enugu, Nigeria. 88 95.

Olomu, J. M. 1995. Monogastric Animal Nutrition: Principles and Practice. Jachem Pub. Benin, Nigeria. 80 98.
Oluyemi J. A. and Roberts F. A. 2000. Poultry Production in Warm Wet Climate. $2^{\text {nd }}$ ed. Spectrum Books Ltd. Ibadan, Nigeria. 210.

Patterson, J. A. and Burkholder, K. M. 2003. Application of prebiotics and probiotics in poultry production. Poult. Sci. 82: 627-631.

Paul, S. K., Samanta, G., Halder, G. and Biswas, P. 2007. Effect of combination of organic acid salts as antibiotic replacer on the performance and gut health of broiler chickens. Livestock Res. RuralDev. 19 (11): 52-61

Steel, R. G. D. and Torrie, J. H. 1980. Principles and Procedures of statistics. McGraw Hill Int. books Co. Sydney.

Sun, X. 2004. Broiler performance and intestinal alterations when fed drug free diets. M.Sc. Thesis, Virginia Polytechnic Institute and State University, Virginia, USA. 96.

Waldroup, A., Kaniawati, S. and Mauromoustakos, A. 1995. Performance characteristics and microbiological aspects of broilers fed diets supplemented with organic acids. J. Food Protection. 58(5): 482 - 489.

Windisch, W., Schedle, K., Plitzner, C. and Kroismayr, A. 2007. Use of phytogenic products as feed additives for swine and poultry. $J$. Anim. Sci. 86 (E. Suppl.): E140 E148.

Received: $15^{\text {th }}$ July, 2016 Accepted: $3^{\text {rd }}$ February, 2017 